\title{
Does improvement in the environmental sustainability rating help to reduce the COVID-19 cases? Controlling financial development, price level and carbon damages
}

\author{
Muhammad Khalid Anser ${ }^{1}$ - Bushra Usman ${ }^{2}$. Shabir Hyder ${ }^{3}$ - Abdelmohsen A. Nassani ${ }^{4} \cdot$ Sameh E. Askar ${ }^{5}$. \\ Khalid Zaman ${ }^{6}$. Muhammad Moinuddin Qazi Abro ${ }^{4}$
}

Received: 13 March 2021 / Accepted: 6 April 2021 / Published online: 3 May 2021

(C) The Author(s), under exclusive licence to Springer-Verlag GmbH Germany, part of Springer Nature 2021

\begin{abstract}
The study's objective is to evaluate the impact of environmental sustainability rating, financial development, changes in the price level and carbon damages on the new COVID-19 cases in a cross-sectional panel of 17 countries. The study developed two broad models to analyse the relationship between the stated factors at the current level and forecast level. The results show that improvement in the environmental sustainability rating and financial efficiency reduces the COVID-19 cases, while continued economic growth and changes in price level likely to exacerbate the COVID-19 cases across countries. The forecast results suggest the U-shaped relationship between COVID-19 cases and carbon damages controlling financial development, price level and environmental sustainability rating. The variance decomposition analysis shows that carbon damages, environmental sustainability rating and price level changes will largely influence COVID-19 cases over the next year. The soundness of economic and ecological regulated policies would be helpful to contain coronavirus cases globally.
\end{abstract}

Keywords Environmental sustainability rating · Carbon damages · COVID-19 pandemic · Financial development, price level · Robust least squares regression

\section{Introduction}

The COVID-19 pandemic brings many new challenges and opportunities for economies to correct their economic, environmental and healthcare policies to minimize global

Responsible Editor: Nicholas Apergis

Khalid Zaman

khalid_zaman786@yahoo.com

Muhammad Khalid Anser

mkhalidrao@xauat.edu.cn; khalidsnnu@yahoo.com

Abdelmohsen A. Nassani

Nassani@ksu.edu.sa

Sameh E. Askar

saskar@ksu.edu.sa

Muhammad Moinuddin Qazi Abro

mqazi@ksu.edu.sa

1 School of Public Administration, Xi'an University of Architecture and Technology, Xi'an 710000, China healthcare losses. The data for a recent rise in coronavirus infected cases in 17 countries helps to assess the emergence of a second possible wave of infectious disease at a massive scale. The history of infectious diseases is as old as human civilization. Human progress is associated with many of its
2 School of Management, Forman Christian College (A Chartered University), Lahore, Pakistan

3 Department of Management Sciences, COMSATS University Islamabad Attock Campus, Attock, Pakistan

4 Department of Management, College of Business Administration, King Saud University, P.O. Box 71115, Riyadh 11587, Saudi Arabia

5 Department of Statistics and Operations Research, College of Science, King Saud University, P.O. Box 11451, Riyadh 11587, Saudi Arabia

6 Department of Economics, University of Haripur, Haripur Khyber Pakhtunkhwa, Pakistan 
sufferings. Some of the most challenging and prominent pathogens are presented in Table 1 for ready reference.

The rise in the COVID-19 pandemic alarmed the globalized world to re-focused on the earlier suggested policies to contain infectious diseases. Simultaneously, it has highly needed to assess the leading causes of the deadly contagious diseases again spread out from the boundary. The main focal point of the earlier suggested policies, especially to control COVID-19, was to maintain social distancing, using a preventive mask, and handwashing which was considered the critical strategy to contain coronavirus cases (Wang et al. 2020; Lima-Costa et al. 2020). The number of scholarly writing in support of the suggested economic policies is evident. The conclusive, critical remarks of the earlier findings are as follows, i.e. social distancing helpful to minimize the risk of communicable diseases, including COVID-19 as its spread through close contact, person-to-person transmitted through sneezing, cough, and flu, and lack of necessary handwashing facilities (Wimalawansa 2020). There will be a high need to make our cities more planned to diffuse population per square $\mathrm{km}$ of land area. Hence, infectious diseases may be less likely to get infused through close living. The greater need to increase healthcare expenditures in national healthcare bills is desirable to confront epidemic diseases (Schwarz 2021; The New York Times 2020). The marginalized population should need quick healthcare and economic reforms, as infectious diseases, including COVID-19, more likely to affect the poor community, which can cause the spread of contagious diseases to other people. The relief package should be announced for poor people not limited to cash, while to give knowledge about the way of spread infectious diseases from one to another, and what precautions are needed to escape out from it. The government needs to offer some home-based jobs to their poor people, such as giving sewing machines to the poorer women and affiliated with some SMEs that help to stay at their homes and do their work to get some income from it (Anser et al. 2020a).
Daily wage employees, small-sized shop keepers, barbers' shops and unemployed people suffered from infectious diseases, including COVID-19. The complete city lockdown for 15 to 20 days to prevent epidemic diseases can mainly hit these peoples. They earned a minimum income that insufficient to convert into household savings and unable to utilize lockdown days to meet their families (Sinclair et al. 2020). The government should have to take responsibilities for these families, engage them in their houses by providing direct cash or providing foodstuff at home, or introduce some online work, supporting their families in unprecedented time (Kansiime et al. 2021). The government should give a bailout package of a large sum of money to the financial and business enterprises by providing low interest or zero interest base loans to the industries to keep running their production (Bartik et al. 2020). Insurance companies increase interest premium due to impulsive situation; thus, this sector also bailout either through an allocated fund to prevent epidemic diseases or through any other policies so that economic activities could be stable (Banthin et al. 2020).

The service sector reforms also suggested in the earlier studies to sustain the tourism business during the COVID-19 pandemic, i.e. the people engaged with the tourism sector, transportation, small- and medium-sized enterprises and the construction sector primarily influenced by the epidemic diseases. The rural segment is mainly dependent on international tourism; hence, due to transmitted infectious diseases, inbound tourism substantially declines, which ultimately affect their livelihood (Gaffney and Eeckels 2020). The multifaceted challenges could come simultaneously; thus, the government should not wait for any natural disaster while keeping planning a good day for unwanted bad days (Hadjidemetriou et al. 2020). Table 2 shows the current literature review on infectious diseases across countries.

The sustainability agenda compromised in the wake of the COVID-19 pandemic. The sustainable development projects

Table 1 Prominent epidemics, outbreaks and pandemics

\begin{tabular}{lllll}
\hline Pathogen & Year & Cases/mortality & Geographical location & References \\
\hline Influenza (Spanish flu) & $1918-1920$ & 100 million deaths out of 500 million cases & China to worldwide & Saunders-Hastings and \\
Influenza (Asian flu) & $1957-1958$ & 2 million deaths & China to worldwide & Krewski (2016) \\
HIV/AIDS & 1960 -to date & 32 million deaths out of 75 million cases & Africa to worldwide & WHO (2018) \\
Cholera & 1961 -to date & 29,000 deaths out of 5 million per year & South Asia to worldwide & WHO (2019) \\
Influenza (Hong Kong flu) & $1968-1969$ & 2 million deaths & China to worldwide & SinoBiological (2020) \\
SARS & $2002-2003$ & 800 deaths out from 8000 & China to 37 countries & Chesak (2020) \\
Influenza (Swine flu) & $2009-2010$ & 6 million deaths & Mexico to worldwide & Bloom and Cadarette (2019) \\
Ebola & $2014-2016$ & 11,325 deaths out from 28,600 & West Africa & CDCP (2017) \\
Zika & $2015-$ to date & No confirms deaths & Brazil and America & Partlow (2016) \\
Dengue & 2016 & 38,000 deaths out of 100 million & Worldwide & Institute for Health Metrics \\
& & & and Evaluation (2019) \\
Coronavirus (COVID-19) & $2019-2020$ & 26,495 deaths out of 571,678 cases in four months & China to worldwide & WHO (2020) \\
\hline
\end{tabular}


and green innovation programs are halts due to the exacerbation of COVID-19 cases. Environmental knowledge is highly needed to promote green behaviour, which possibly is effective through advancement in ethical leadership (Ahmad et al. 2021). Individual green values also in line with the promotion of ethical leadership to support green human resource development (Islam et al. 2020a). Technology advancement played a vital role to conceive a green and clean environmental agenda, which is imperative for long-run sustained economic growth (Batool et al. 2019). Corporate social responsibility and green environmental behaviours help achieve the sustainability agenda (Islam et al. 2019). The resulting impact of the COVID-19 pandemic was limited to the deteriorating healthcare sustainability agenda. Simultaneously, the food retail business and customer's mistreatment also affected, which need pro-active resource agenda to treat customers more efficiently (Ahmed et al. 2021). Communicable diseases, including COVID-19, increase healthcare expenditures leading to global depression (Anser et al. 2020b). Information technologies help disseminate the susceptibility rate of coronavirus cases and update the latest information to take preventive measures worldwide (Islam et al. 2020b).

Based on the earlier literature, the study could get a research gap between environmental sustainability and COVID-19 cases from different perspectives. First, the previous studies mainly used carbon emissions as an environmental proxy in the relationship of COVID-19 pandemic (see Han et al. 2021; Balsalobre-Lorente et al. 2020; Le Quéré et al. 2020), while this study used environmental sustainability rating index, which gives new insights of the relationship to control COVID-19 cases. Second, the study used money supply as financial development proxy in the COVID-19 modelling framework to assess the possible impact of financial openness leading to COVID-19 cases. The few studies worked on the relationship between financial development and COVID-19 cases (see Anser et al. 2021; Humpe and McMillan 2020; Silaswara et al. 2020). However, this study also used the financial indicator in new predicted COVID-19 cases, giving more insights into the relationship at intertemporal settings. Finally, the study used carbon damages and its square term in the forecasted COVID-19 cases modelling framework, which does not previously address the nonlinearity in the later stages of exacerbating COVID-19 cases. This unique contribution of the study opens many new avenues in the scholarly writings, enabling policymakers to devise sustainable environmental policies worldwide.

The study comprehensively discussed the possible vulnerabilities of the COVID-19 pandemic. It focused on the re-emergence of coronavirus cases as a possible second wave in many parts of the globalized world that need to be contained through solicited efforts. The study found some new and vital factors requiring careful examination to control them with sound global economic policies. After the first wave of COVID-19, the government used easy economic policies to support their financial and business affairs. The high socialization and commercialization process among the economic agents would probably be the more significant cause of the re-emergence of newly infected coronavirus cases across countries. Based on this assumption, the study evaluated many essential factors as research objectives of the study, i.e.

To critically examine the government policies in terms of socialization and commercialization that likely to a new rise in coronavirus infected cases.

ii) To analyse the cost of carbon emissions that would be the possible cause of re-emergence of the high level of newly infected coronavirus cases across countries, and

iii) To assure improvement in the environmental sustainability ratings that probably begins to decline coronavirus cases at a massive scale.

These objectives would be evaluated through panel crosssectional statistical techniques and would help reach some conclusive findings. The government should have to make all policies in good time. If any epidemic plague arises in the future, the government efficiently managed their resources and fought the epidemic diseases.

\section{Data source and methodological framework}

The study used the following critical predictors of the second wave of possible COVID-19 pandemic that can view in the new infected cases (denoted by NEW) in 17 countries, i.e. carbon damages (denoted by CDAM) as \% of GNI, money supply (denoted by M2) as \% of GDP, GDP per capita (denoted by GDPPC) in constant 2010 US\$, inflation-consumer price index (denoted by CPI) in annual $\%$ and CPIA policy and institutions for environmental sustainability rating (denoted by ESR) $(1=$ low to $6=$ high $)$ index value. The stated factors' data on the current period were taken from Worldometer (2020) and World Bank (2020). Figure 1 shows the rise in the newly infected cases in 17 countries for ready reference.

The given variables used to represent different economic substitutions to observe more critical scenario of the possible second wave of COVID-19 pandemic across countries, i.e.

i) New infected COVID-19 cases (NEW): The rise in the new infected COVID-19 cases, used as a 'response' variable. It served as a possible factor for identifying the second wave of COVID-19 cases across countries. The increase in new cases found in 17 countries collected from the Worldometer (2020) on $19^{\text {th }}$ October 2020. 
Table 2 Current literature on different communicable diseases (including COVID-19) and healthcare expenditures

\begin{tabular}{|c|c|c|c|c|c|c|}
\hline Authors & Country & $\begin{array}{l}\text { Communicable } \\
\text { diseases }\end{array}$ & Causes/symptoms & Consequences & Prevention & Medication \\
\hline $\begin{array}{l}\text { Fukuda et al. } \\
\qquad(2020)\end{array}$ & Japan & $\begin{array}{l}\text { Hepatitis } \mathrm{C} \text { virus } \\
\quad(\mathrm{HCV})\end{array}$ & Liver failure & $\begin{array}{l}\text { Healthcare expenditures } \\
\text { increases in age groups. }\end{array}$ & $\begin{array}{l}\text { The need for economical } \\
\text { and effective drug } \\
\text { therapies would be } \\
\text { beneficial for HCV } \\
\text { patients. }\end{array}$ & $\begin{array}{l}\text { Oral and injectables are available } \\
\text { for HCV-infected people. }\end{array}$ \\
\hline $\begin{array}{l}\text { Ward et al. } \\
\qquad(2020)\end{array}$ & US & HIV management & $\begin{array}{l}\text { HIV is a sexually transmitted } \\
\text { disease, while it further } \\
\text { spread with infected blood } \\
\text { and breastfeeding. It } \\
\text { damages the immune system } \\
\text { that affects the quality of life } \\
\text { of the patient. }\end{array}$ & $\begin{array}{l}\text { The HIV patients could bear not } \\
\text { only the cost of the therapy } \\
\text { while it has associated with } \\
\text { some other toxicities, } \\
\text { including cardiovascular } \\
\text { disease, kidney issues and } \\
\text { osteoporosis. }\end{array}$ & $\begin{array}{l}\text { The life expectancy can } \\
\text { increase with the } \\
\text { associated cost of the } \\
\text { therapy. }\end{array}$ & $\begin{array}{l}\text { There is no such cure rate of HIV } \\
\text { patients while symptomatic } \\
\text { treatment is given to the } \\
\text { patients to increase life } \\
\text { expectancy. }\end{array}$ \\
\hline $\begin{array}{l}\text { Njau et al. } \\
\text { (2019) }\end{array}$ & Romania & $\begin{array}{l}\text { Measles and } \\
\text { rubella }\end{array}$ & $\begin{array}{l}\text { Rashes, fever, lymph nodes, flu, } \\
\text { headache, red eyes, etc. }\end{array}$ & $\begin{array}{l}\text { The cost of measles and rubella } \\
\text { outbreaks was US\$9.9 } \\
\text { million, among which } \\
\text { measles and rubella per cost } \\
\text { of patients were around the } \\
\text { US } \$ 439 \text { and US } \$ 132 \text {, } \\
\text { respectively. Further, the } \\
\text { result indicates that about } \\
36 \% \text { of households could not } \\
\text { afford this high viral cost, thus } \\
\text { have to borrow it from other } \\
\text { sources. }\end{array}$ & $\begin{array}{l}\text { Routine vaccination would } \\
\text { be helpful to reduce the } \\
\text { economic burden. }\end{array}$ & $\begin{array}{l}\text { MMR vaccine primarily used for } \\
\text { this viral disease. }\end{array}$ \\
\hline $\begin{array}{l}\text { Pedrazzoli } \\
\text { et al. } \\
\text { (2019) }\end{array}$ & $\begin{array}{l}\text { A general } \\
\text { survey } \\
\text { across } \\
\text { countries }\end{array}$ & Tuberculosis & $\begin{array}{l}\text { TB is more prone due to } \\
\text { poverty, lack of knowledge, } \\
\text { income and financial issues. }\end{array}$ & $\begin{array}{l}\text { The economic consequences are } \\
\text { apparent, which includes } \\
\text { reduced labour supply, low } \\
\text { labour productivity, less } \\
\text { income and household } \\
\text { resilience. }\end{array}$ & $\begin{array}{l}\text { TB DOTS programme, } \\
\text { patient-centred TB ser- } \\
\text { vices and free medi- } \\
\text { cines given to the needy } \\
\text { people would help cure } \\
\text { this disease. }\end{array}$ & $\begin{array}{l}\text { The four-drug therapy primarily } \\
\text { used in the first phase then } \\
\text { decrease up to three or two } \\
\text { medicines. It is around } 6 \text { to } 8 \\
\text { months of medication treat- } \\
\text { ment that is curable. }\end{array}$ \\
\hline $\begin{array}{l}\text { Albuquerque } \\
\text { et al. } \\
\text { (2019) }\end{array}$ & Brazil & Zika virus & $\begin{array}{l}\text { Children are affected mainly by } \\
\text { the Zika virus, leading to } \\
\text { cognitive impairment, } \\
\text { epilepsy, visual problems } \\
\text { and arthrogryposis. }\end{array}$ & $\begin{array}{l}\text { The low priority areas, } \\
\text { marginalized population and } \\
\text { inability to afford healthcare } \\
\text { prices affected mainly by the } \\
\text { Zika virus. }\end{array}$ & $\begin{array}{l}\text { Frequent healthcare visits } \\
\text { and regular follow-up } \\
\text { with the physicians } \\
\text { would positively pre- } \\
\text { vent the Zika virus. }\end{array}$ & $\begin{array}{l}\text { There is no specific vaccine and } \\
\text { medicine; thus, it mainly } \\
\text { treats it through symptomatic } \\
\text { medication. }\end{array}$ \\
\hline $\begin{array}{l}\text { Kum et al. } \\
\text { (2019) }\end{array}$ & $\begin{array}{l}\text { Sierra } \\
\text { Leone }\end{array}$ & Ebola virus & $\begin{array}{l}\text { Unexplained haemorrhaging is } \\
\text { the main symptom. }\end{array}$ & $\begin{array}{l}\text { The disease negatively affects the } \\
\text { country's budget due to the } \\
\text { affected countries' food and } \\
\text { mining business disclosure. }\end{array}$ & $\begin{array}{l}\text { Clinical care and the } \\
\text { patient's immune } \\
\text { response would mainly } \\
\text { prevent it from this } \\
\text { disease. }\end{array}$ & $\begin{array}{l}\text { The FDA approves the Ebola } \\
\text { vaccine rVSV-ZEBOV. }\end{array}$ \\
\hline $\begin{array}{l}\text { Bai et al. } \\
(2020)\end{array}$ & China & COVID-19 & $\begin{array}{l}\text { Viral pneumonia resulted in the } \\
\text { outbreak of coronavirus. }\end{array}$ & $\begin{array}{l}\text { Fever, cough, body pain and } \\
\text { respiratory problems are } \\
\text { common symptoms. }\end{array}$ & $\begin{array}{l}\text { Social distancing suggests } \\
\text { prevention. }\end{array}$ & $\begin{array}{l}\text { There is no such vaccine or } \\
\text { medicine for this viral } \\
\text { infection. Self-isolation and } \\
\text { quarantine hospitals/places } \\
\text { recommended. }\end{array}$ \\
\hline $\begin{array}{l}\text { Grasselli } \\
\quad \text { et al. } \\
(2020)\end{array}$ & Italy & COVID-19 & $\begin{array}{l}\text { The severe acute respiratory } \\
\text { syndrome coronavirus } 2 \\
\text { (SARS-CoV-2) lead to } \\
\text { COVID-19. }\end{array}$ & $\begin{array}{l}\text { Treatment that does not respond } \\
\text { to atypical pneumonia may } \\
\text { lead to COVID-19. }\end{array}$ & $\begin{array}{l}\text { Intensive care units build } \\
\text { up and allocated for } \\
\text { COVID-19 patients. }\end{array}$ & $\begin{array}{l}\text { Set up local procedures for the } \\
\text { triage of patients with } \\
\text { respiratory issues. }\end{array}$ \\
\hline $\begin{array}{l}\text { Adalja et al. } \\
\quad(2020)\end{array}$ & US & COVID-19 & $\begin{array}{l}\text { SARS-CoV-2 lead to } \\
\text { COVID-19. }\end{array}$ & $\begin{array}{l}\text { Healthcare workers are mainly in } \\
\text { danger to expose directly to } \\
\text { COVID-19 patients. }\end{array}$ & $\begin{array}{l}\text { The need for a proper } \\
\text { healthcare system is } \\
\text { required to confront } \\
\text { this disease. }\end{array}$ & $\begin{array}{l}\text { Diagnostic testing, local } \\
\text { hospitals and clinics need to } \\
\text { move quickly forward to } \\
\text { tackle the disease. }\end{array}$ \\
\hline $\begin{array}{l}\text { Murthy et al. } \\
\text { (2020) }\end{array}$ & $\begin{array}{l}\text { General } \\
\text { survey }\end{array}$ & COVID-19 & $\begin{array}{l}\text { The SARS, the Middle East } \\
\text { respiratory syndrome and } \\
\text { different severe influenza, } \\
\text { including } \mathrm{A}(\mathrm{H} 7 \mathrm{~N} 9) \text { and } \\
\mathrm{A}(\mathrm{H} 1 \mathrm{~N} 1) \text {, are the integral } \\
\text { components of this } \\
\text { infectious disease. }\end{array}$ & $\begin{array}{l}\text { Older patients (median age } \approx 60 \\
\text { years) are affected mainly by } \\
\text { this virus, while milder } \\
\text { illnesses found in children. }\end{array}$ & $\begin{array}{l}\text { Increase urine intensity, } \\
\text { lung-protective ventila- } \\
\text { tion and reduced lung } \\
\text { inflation are recom- } \\
\text { mended for possibly } \\
\text { minimizing the severity } \\
\text { of this disease. }\end{array}$ & $\begin{array}{l}\text { An early antibiotic for } \\
\text { symptomatic treatment } \\
\text { suggested following some } \\
\text { other healthcare guidelines to } \\
\text { confront this virus; however, } \\
\text { there is no such specific } \\
\text { vaccine/medicine until yet } \\
\text { launched to reduced mortal- } \\
\text { ities. Precaution is the only } \\
\text { medicine. }\end{array}$ \\
\hline
\end{tabular}

The study simulated more infected cases based on the given data, and it has been used as a central stimulus to direct more critical factors to the healthcare agenda. ii) Environmental sustainability agenda: The study used two different environmental factors that would probably be a cause an increase in newly infected cases, 

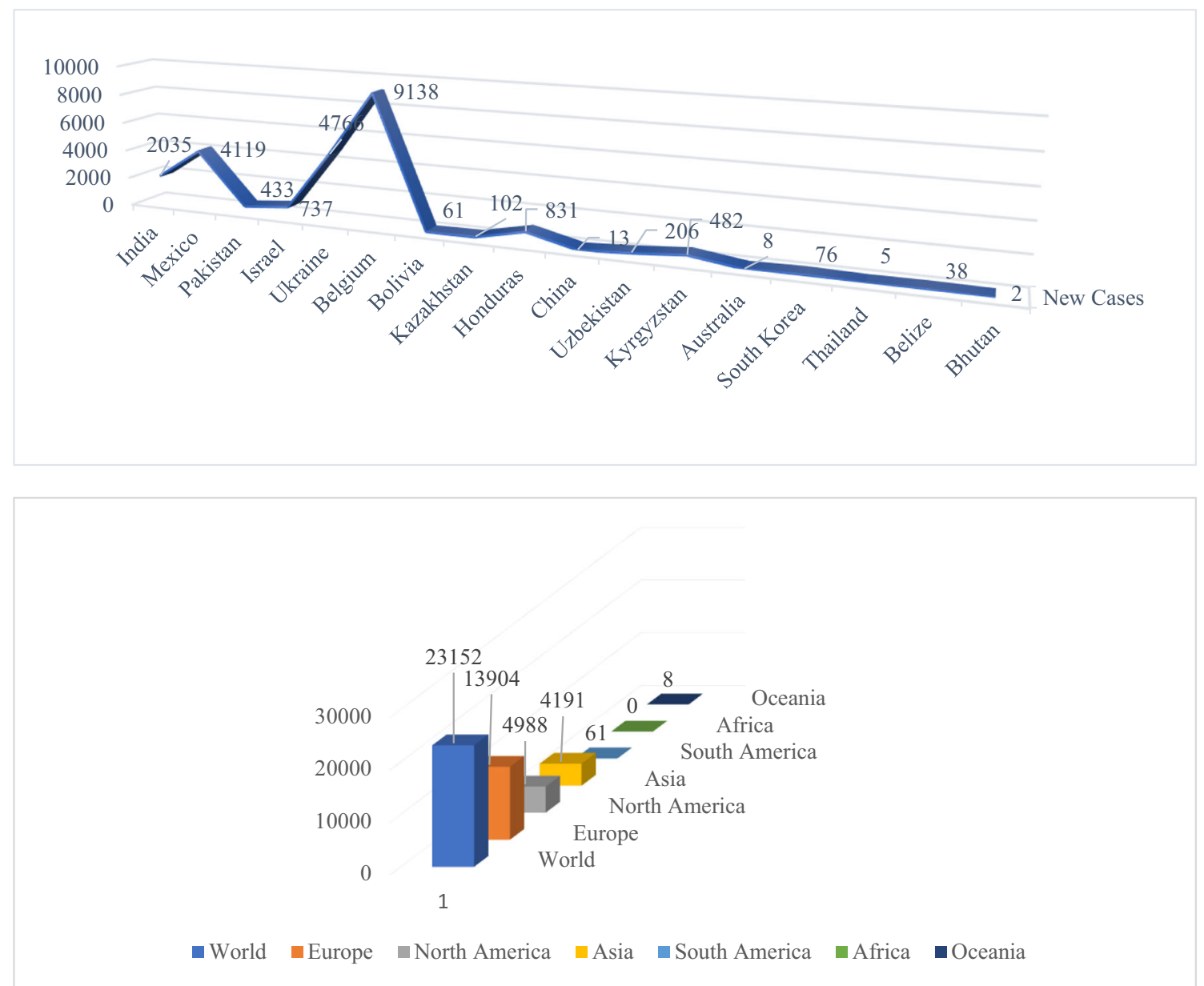

Fig. 1 Rise in new infected COVID-19 cases. Source: Worldometer (2020, dated 19th October 2020

including carbon damages and environmental regulations. It assumed that an increase in carbon emissions damages the healthcare sustainability agenda. Hence, a person with infectious diseases in a healthcare constraint environment has more incidence to get infected (Anser et al. 2020c). The second factor is environmental regulation, which assessed through a rating index. The more significant environmental regulations would enable to minimize the incidence of infectious diseases and helpful to sustained healthcare activities.

iii) Socialization: The more significant change in money supply and continued economic growth leads to an increase in more economic activity that probably is a cause of more social interaction among the economic agents, which may lead to getting infected from
COVID-19 cases. The monetary transactions in healthcare infrastructure provision would enable us to get back off from infectious diseases, including COVID-19.

iv) Commercialization: The commercial activities exacerbated after the first wave of the COVID-19 pandemic. The commodity prices increase due to the high demand for the goods that obstructed during the COVID-19 epidemic. This situation would cause the second wave of COVID-19 pandemic, which needs to be lookup with sound economic policies.

Based on the stated discussion, the study made the following equation to assess the possible cause of the second wave of COVID-19 pandemic across countries, i.e.

$\ln (N E W)=\alpha_{0}+\alpha_{1} \ln \left({ }_{E}+\alpha_{2} \ln \left({ }_{M}+\alpha_{3} \ln (\mathrm{GDPPC})_{17,2020}+\alpha_{4} \ln \left({ }_{C}+\varepsilon_{17,2020} \therefore \frac{\partial \ln (N E W)}{\partial \ln (E S R)}<0, \frac{\partial \ln (N E W)}{\partial \ln (M S)} \cdot>0, \frac{\partial \ln (N E W)}{\partial \ln (G D P P C)}>0, \frac{\partial \ln (N E W)}{\partial \ln (C P I)}>0\right.\right.\right.$ 
Where ln shows natural logarithm, NEW shows newly infected cases, ESR shows environmental sustainability rating, MS shows money supply, GDPPC shows GDP per capita, CPI shows inflation, 'In' shows natural logarithm and $\varepsilon$ shows error term.
Equation (1) shows that improvement in the environmental sustainability rating would reduce newly infected coronavirus cases. In contrast, economic policies and commercial activities would cause a recent rise in COVID-19 cases across countries. The study further simulated newly infected patients based on Eq. (1) and estimated Eq. (2), i.e.

$$
\begin{array}{r}
\ln (N E W F)=\alpha_{0}+\alpha_{1} \ln \left({ }_{C}+\alpha_{2} \ln \left({ }_{S}+\alpha_{3} \ln \left({ }_{E}+\alpha_{4} \ln \left({ }_{M}+\alpha_{5} \ln \left({ }_{G}+\alpha_{6} \ln \left({ }_{C}+\varepsilon_{17,2020} \therefore \frac{\partial \ln (N E W F)}{\partial \ln (C D A M)}<0, \frac{\partial \ln (N E W F)}{\partial \ln (S Q C D A M)}>0, \frac{\partial \ln (N E W F)}{\partial \ln (E S R)}\right.\right.\right.\right.\right.\right. \\
<0, \frac{\partial \ln (N E W F)}{\partial \ln (M S)} .>0, \frac{\partial \ln (N E W F)}{\partial \ln (G D P P C)}>0, \frac{\partial \ln (N E W F)}{\partial \ln (C P I)}>0
\end{array}
$$

Where NEWF shows forecasted newly infected cases, CDAM shows carbon damages and SQCDAM shows a square of CDAM.

Equation (2) shows that carbon damages exhibit a curvy linear relationship with new forecasted coronavirus cases with a negative and positive sign at the initial and final environmental degradation level. Figure 2 shows the research framework of the study.

Figure 2 shows that the second wave of possible spread of COVID-19 cases is probably the cause of the high level of commercial activities and economic socialization due to expansionary monetary policies, which increases the money supply and credit creation across countries. The increased need for healthcare spending would support environmental sustainability rating while decreasing infectious diseases on a massive scale. The following hypotheses proposed to test the possible cause of an increase in COVID-19 cases across countries, i.e.

H1: It is a likelihood that an increase in commercialization activities and socialization leads to a rise in newly infected coronavirus cases.
Fig. 2 Research framework. Source: Self-extract

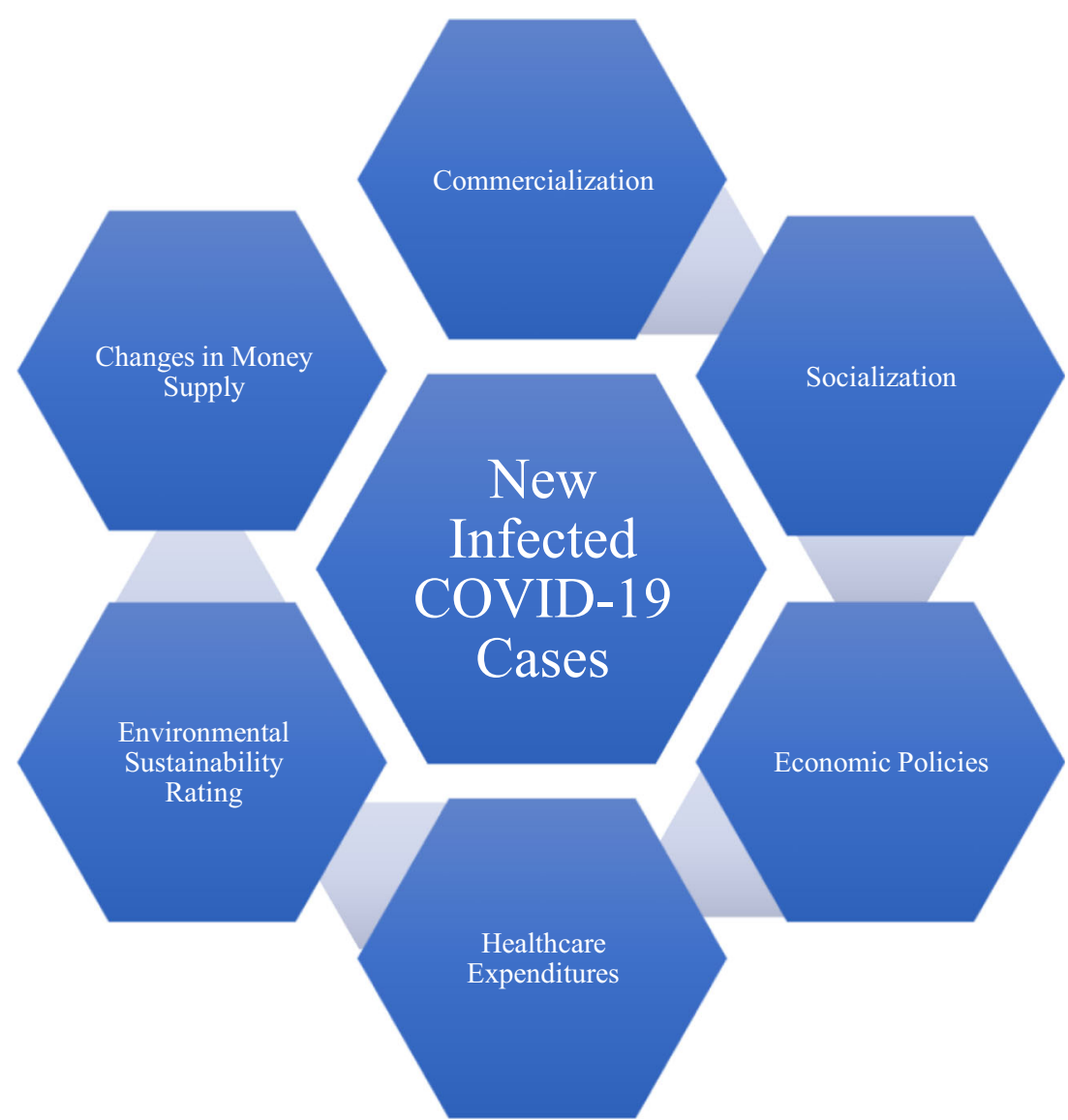


The study hypothesizes that increasing commercialization activities through the stock market's upsurge begins to rise new COVID-19 cases. Increasing close contacts between economic agents in buying and selling process leads to more epidemic challenges, which need to be contained by managing standardized operating procedures.

H2: The easy economic policies likely to bind close connection between economic agents and suppliers that increases corporate payoffs at the expense of healthcare damages.

The second hypothesize more focused on the expansionary fiscal and monetary policy, where government spending increases on public goods and interest rate declines, leading to more investment in the economy that exacerbates the susceptibility of increasing new COVID-19 cases across countries, and

H3: Environmental sustainability rating would likely improve through increasing healthcare spending across countries.

Finally, the third hypothesis is more focused on maintaining the environmental sustainability rating that improves the quality of life and healthcare infrastructure, leading to reducing the risk of increasing COVID-19 cases globally.

These hypotheses have empirically tested by robust least square regression apparatus and variance decomposition analysis. The economic relationship checked by ordinary least square regression; however, this procedure has certain limitations that cannot minimize possible outliers from the stimulus variable and its regressand. The greater need for handling potential outliers in cross-sectional models, where the country size has variated as per their factor endowment, required more robust regression to minimize structural adjustment shocks across the cross-sections. The robust least square regression gives more sound inferences to absorb complete outliers across cross-sections and provides sound parameter estimates. The VAR economic modelling offers facilitation to assess innovation shocks in the stimulus variable about the regressand over a while. Both the empirical modelling techniques enable one to mark some conclusive findings.

\section{Results and discussion}

Table 3 shows the descriptive statistics of the candidate variables. The minimum increase in newly infected cases is 2 , and the maximum points reached 9138 with a mean value of 1356 . The carbon damages, changes in the price level and environmental sustainability rating have a mean value of $2.607 \%$ of GNI, 3.174\% and 3.117 index point, respectively. The per
Table 3 Descriptive statistics

\begin{tabular}{lllllll}
\hline Methods & NEW & CDAM & CPI & ESR & GDPPC & MS \\
\hline Mean & 1356 & 2.607 & 3.174 & 3.117 & $13,371.53$ & 77.672 \\
Maximum & 9138 & 5.618 & 10.578 & 4 & $57,071.17$ & 197.017 \\
Minimum & 2 & 0.613 & 0.382 & 3 & 1116.358 & 17.831 \\
Std. Dev. & 2472.148 & 1.722 & 3.044 & 0.281 & $17,593.98$ & 48.125 \\
Skewness & 2.177 & 0.686 & 1.150 & 2.249 & 1.478 & 0.990 \\
Kurtosis & 6.913 & 2.108 & 3.237 & 6.925 & 3.763 & 3.352 \\
\hline
\end{tabular}

Note: NEW shows new infected cases, CDAM shows carbon damages, CPI shows inflation, ESR shows environmental sustainability rating, GDPPC shows per capita GDP and MS shows money supply

capita income has a minimum amount of US\$1116.358, a maximum value of US\$57,071.17 and a mean value of US $\$ 13,371.53$. The money supply has reached an average amount of $77.672 \%$ across countries.

Table 4 shows the estimates of robust least square regression and found that environmental sustainability rating and economic policies regarding healthcare money supply on infrastructure development mainly decrease new coronavirus infected cases with elasticity estimates of $-16.703 \% p<$ 0.000 and $-3.09 \% p<0.000$, respectively. The result implies that environmental regulations supporting an increase in healthcare expenditures would help minimize new coronavirus cases (Rupani et al. 2020; Allam and Jones 2020). Further needed global economic actions to mitigate climate changes through an increase in R\&D expenditures (Eissa 2020), healthcare logistics supply (Govindan et al. 2020), testing and labs facility (Pulia et al. 2020), knowledge spillover (Anser et al. 2020b) and implementation of healthcare guidelines associated SOPs at a significant level (Smith et al. 2020).

Table 4 Robust least squares regression estimates for Eq. (1)

\begin{tabular}{lllll}
\hline \multicolumn{2}{l}{ Dependent variable: $\ln (\mathrm{NEW})$} & & & \\
\hline Variable & Coefficient & Std. Error & z-Statistic & Prob. \\
\hline $\mathrm{C}$ & 29.004 & 5.460 & 5.311 & 0.000 \\
$\ln (\mathrm{ESR})$ & -16.703 & 3.487 & -4.789 & 0.000 \\
$\ln (\mathrm{GDPPC})$ & 0.888 & 0.244 & 3.626 & 0.000 \\
$\ln (\mathrm{CPI})$ & 0.814 & 0.280 & 2.899 & 0.003 \\
$\ln (\mathrm{MS})$ & -3.095 & 0.448 & -6.895 & 0.000 \\
Robust statistics & & & & \\
$R^{2}$ & & 0.526 & Adjusted $R^{2}$ & 0.369 \\
$\mathrm{Rw}{ }^{2}$ & & 0.939 & Adjust $\mathrm{Rw}^{2}$ & 0.939 \\
$\mathrm{AIC}$ & & 44.014 & SIC & 51.055 \\
$\mathrm{Rn}^{2}$ & 85.478 & Prob $\left(\mathrm{Rn}^{2}\right)$ & 0.000 \\
\hline
\end{tabular}

Note: NEW shows new infected cases, CPI shows inflation, ESR shows environmental sustainability rating, GDPPC shows per capita GDP and MS offers money supply 
The results further show that commercialization and socialization are the two main predictors that mainly cause a rise in the newly infected coronavirus cases. Socialization has a greater magnitude, i.e. $0.888 \%, p<0.000$ in terms of commercialization, i.e. $0.814 \%, p<0.003$, that exacerbate a second possible incidence wave of coronavirus across selected countries. The high socialization and commercialization activities among economic agents would probably overlook the COVID-19 guidelines that lead to the newly infected coronavirus cases (Silveira et al. 2020; Kutscher and Greene 2020). The greater need for maintaining social distancing (WilderSmith and Freedman 2020), wearing face masks (Wu et al. 2020), avoid physical contacts (Razai et al. 2020) and use hand washing facilities (Cavanagh and Wambier 2020) are essential from prevention of new rise in COVID-19 cases across countries. Table 5 shows the diagnostic testing estimates to comprehend the given results.

Table 5 confirms that the cross-section variables have no potential multicollinearity issue, as the value of VIF is less than the threshold value of 10 . The other statistics confirmed that the given variables have no normality, autocorrelation, heteroskedasticity and model specification. Figure 3 shows the model stability at their $5 \%$ level of significance.

As illustrated in Fig. 3, the model stability estimates confirm that the given statistics of CUSUM and square of CUSUM fall in the 5\% critical region; thus, the given Eq. (1) of its parameters is statistically stable at provided point of time. Table 6 shows the robust least square regression for Eq. (2) and found a curvy relationship between carbon damages and new forecasted coronavirus cases. Initially, an increase in carbon damages does not respond to the latest possible wave of coronavirus. However, high carbon damages lead to increased healthcare damages that react to the new wave of coronavirus disease later. Thus, it exhibits the Ushaped relationship between them. The result implies that environmental pollution is the cause of healthcare damages that leads to the patient's low immune system that quickly affects any infectious diseases (Kang et al. 2020a, b, Xiang et al.
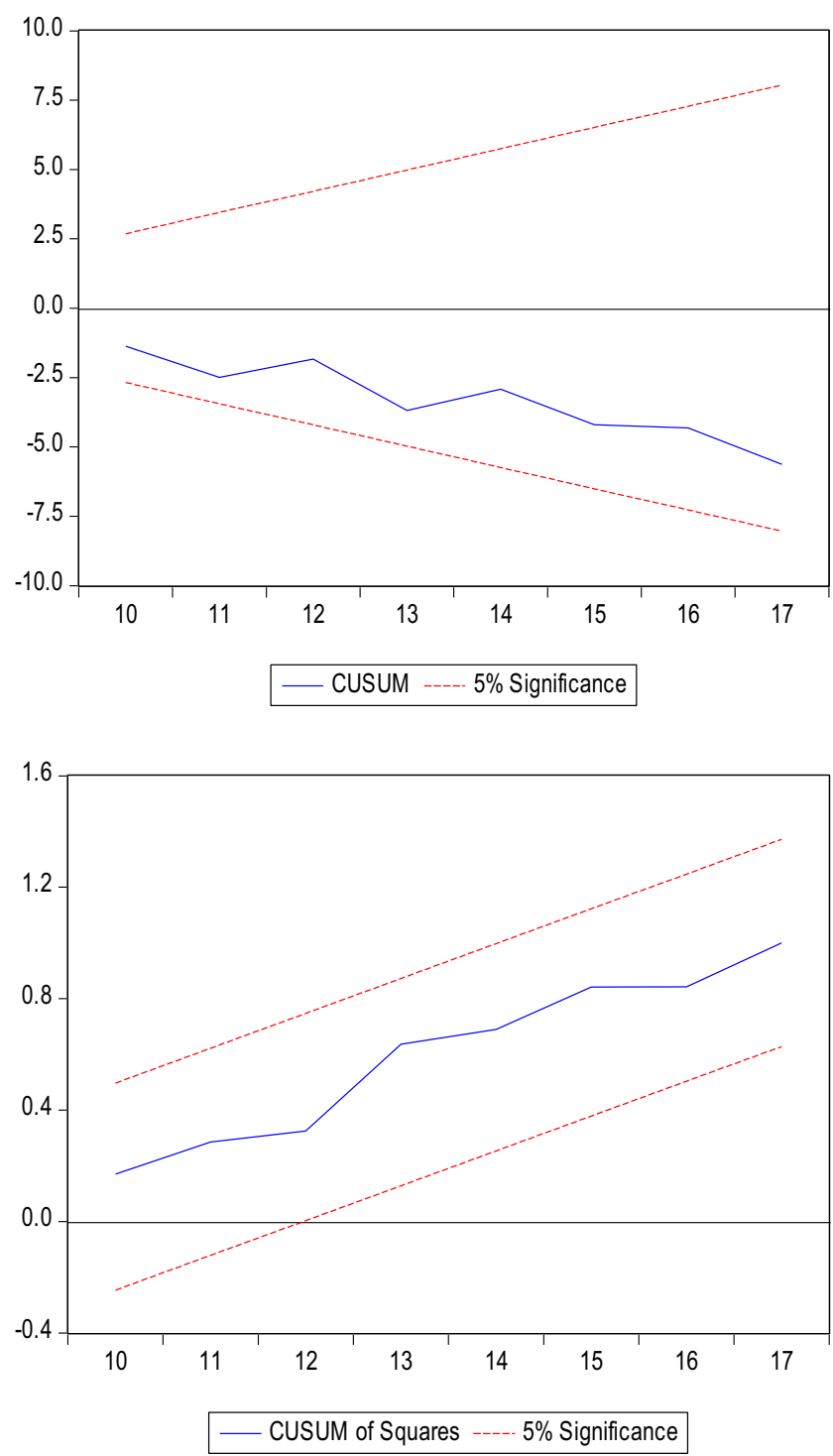

Fig. 3 Model stability tests for Eq. (1). Source: Author's estimate

2020, Lima et al. 2020). The COVID-19 is a deadly contagious disease that infected more quickly ill patients and where
Table 5 Diagnostic test estimates for Eq. (1)

\begin{tabular}{lll}
\hline Variables & Variance inflation factors (VIF) & Other tests \\
\hline $\ln (\mathrm{ESR})$ & 1.135 & JB test: 0.468 \\
& & Prob. Value: $(0.791)$ \\
$\ln (\mathrm{GDPPC})$ & Autocorrelation LM test: 0.565 \\
& 1.313 & $\begin{array}{l}\text { Prob. Value: }(0.585) \\
\text { Heteroskedasticity test: } 1.205\end{array}$ \\
$\ln (\mathrm{CPI})$ & 1.171 & Prob. Value: $(0.358)$ \\
$\ln (\mathrm{MS})$ & 1.120 & $\begin{array}{l}\text { Ramsey RESET test: } 1.242 \\
\text { Prob. Value: } 0.239\end{array}$ \\
\hline
\end{tabular}

Note: CPI shows inflation, ESR shows environmental sustainability rating, GDPPC shows per capita GDP and MS offers money supply 
Table 6 Robust least square regression estimates for Eq. (2)

Dependent variable: $\ln (\mathrm{NEWF})$

\begin{tabular}{lllll}
\hline Variable & Coefficient & Std. Error & z-Statistic & Prob. \\
\hline $\mathrm{C}$ & 29.002 & 1.032 & 28.089 & 0.000 \\
$\ln (\mathrm{CDAM})$ & -0.585 & 0.181 & -3.215 & 0.001 \\
$\ln (\mathrm{SQCDAM})$ & 0.298 & 0.135 & 2.199 & 0.027 \\
$\ln (\mathrm{ESR})$ & -12.623 & 0.646 & -19.528 & 0.000 \\
$\ln (\mathrm{CPI})$ & 0.612 & 0.052 & 11.778 & 0.000 \\
$\ln (\mathrm{MS})$ & -2.352 & 0.117 & -20.096 & 0.000 \\
Robust statistics & & & & \\
$R^{2}$ & & 0.880 & Adjusted $R^{2}$ & 0.826 \\
$\mathrm{Rw}$ & & 0.994 & Adjust $\mathrm{Rw}^{2}$ & 0.994 \\
$\mathrm{AIC}$ & & 20.294 & SIC & 28.889 \\
$\mathrm{Rn}^{2}$ & & 1511.871 & Prob $\left(\mathrm{Rn}^{2}\right)$ & 0.000 \\
\hline
\end{tabular}

Note: NEWF shows new forecast infected cases, CDAM shows carbon damages, SQDAM shows a square of CDAM, CPI shows inflation, ESR shows environmental sustainability rating, GDPPC shows per capita GDP and MS shows money supply

the patients' immune system is critically compromised, thus its cause of spreading infectious diseases (Ogen 2020; Abdi 2020).

The other results show that environmental sustainability regulations would be supportive enough to minimize coronavirus cases' possible re-occurrence. Its possibly be minimized by improving the health hygiene of the patients (Ung 2020), increasing nutritional diets and supplements (BourBour et al. 2020), proper healthcare counselling (Brownstone et al. 2020), (Silva et al. 2020) and mitigating air pollution (Saha and Chouhan 2020). The commercialization activities exacerbate new infectious cases; however, its effect can be minimized through an increase in ease in economic policies to support the healthcare agenda (Shereen et al. 2020). Thus, the greater need for social protection through safety nets programme and employment generated policies would embark

Table 7 Diagnostic test estimates for Eq. (2)

\begin{tabular}{lll}
\hline Variables & VIF & Other tests \\
\hline $\ln (\mathrm{CDAM})$ & 7.158 & $\begin{array}{l}\text { JB test: } 0.941 \\
\text { Prob. Value: }(0.624) \\
\end{array}$ \\
$\ln$ (SQCDAM) & 9.143 & $\begin{array}{l}\text { Autocorrelation LM test: } 1.646 \\
\text { Prob. Value: }(0.245)\end{array}$ \\
$\ln (\mathrm{ESR})$ & 1.202 & Heteroskedasticity test: 0.581 \\
$\ln (\mathrm{CPI})$ & 1.235 & Prob. Value: $(0.713)$ \\
$\ln (\mathrm{MS})$ & 2.347 & \\
\hline
\end{tabular}

Note: CDAM shows carbon damages, SQDAM shows a square of CDAM, CPI shows inflation, ESR shows environmental sustainability rating, GDPPC shows per capita GDP and MS shows money supply on long-term sustained healthcare policies that are pivotal for sustainable development across countries (Akseer et al. 2020). Table 7 shows the diagnostic testing estimates for Eq. (2) for ready reference.

The results confirmed the basic diagnostic statistics that exhibit the 'no common error' related to the usual stochastic characteristics, including the normality issue, serial correlation and heteroskedasticity. VIF value also comprehends the free from the multicollinearity issues among the regressors, which remains inside the threshold value of 10 . The closeness of value near the threshold value of 10 for CDAM and its square term is evident due to the quadratic relationship between the CDAM and NEWF; however, it does not necessarily imply the collinear relationship among the stated variables. This illustration can be view in Fig. 4 for ready reference. The CUSUM and CUSUM square terms confirmed the model's stability for Eq. (2), as it falls inside the 5\% level of confidence.

Table 8 shows that carbon damages and commercialization have a greater magnitude to influence NEW cases and NEWF cases, respectively, over the next 1-year time period. The share of environmental sustainability rating is far more significant in the NEW instances relative to the NEWF cases. Socialization and economic easiness also would likely influence NEW cases and NEWF cases over a while. The share of the money supply is more outstanding in NEW cases relative to NEWF cases during the coming months. These statistics would help assess the current and forecasted trend of a new possible wave of COVID-19 cases across countries.

\section{Conclusions}

The study aims to analyse the possible determinants of a new rise in COVID-19 cases in a panel of 17 global economies. These countries mainly selected due to an increase in COVID-19 new infected cases. The study found three main vital factors that could cause coronavirus diseases, i.e. close socialization among economic agents, more splendid commercialization activities and environmental deregulations. These factors mainly accessed by the continued economic growth, changes in the price level and high carbon damages. The other two main possible factors help minimize healthcare losses, i.e. sound economic policies and improved sustainability rating. These factors have accessed through an increase in money supply and environmental sustainability rating scale.

The number of microorganisms spread in the air and could infect people. For instance, vector-borne and zoonotic diseases, like Ebola, malaria, rabies, etc.; water-and food-borne diseases, like typhoid, dysentery, cholera, etc.; and endemic fungal diseases, like skin problems, dermatitis, etc., are exposed to climate change. Besides some 
Fig. 4 Model stability tests for Eq. (2). Source: Author's estimate

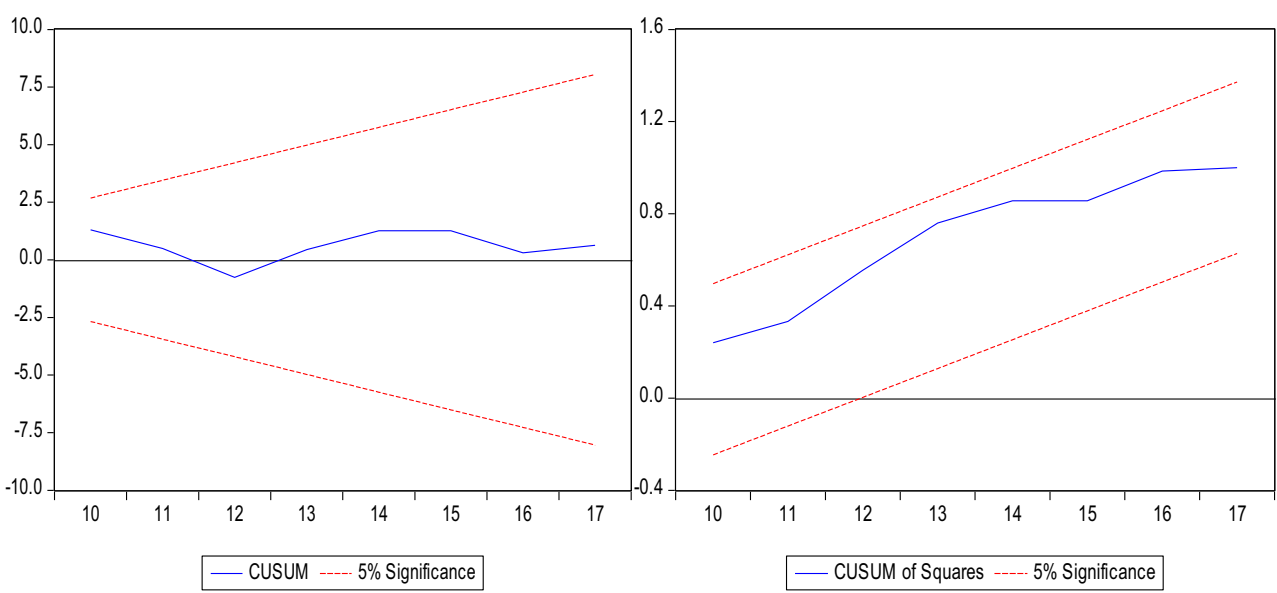

direct measures in the current period, the government should have to plan some long-term policies related to the production of carbon-free goods, strict environmental regulations, the imposition of carbon taxes on dirty industries, healthcare-associated environmental certifications and advancement in cleaner production technologies. All these strategies would help minimize epidemic diseases by mitigating high carbon and fossil fuel combustion at a global scale.

\section{Policy implications}

The study suggested the following five policy implications that would be helpful to control the second possible wave of coronavirus cases, i.e.

i) To monitor 'socialization and commercialization' activities among economic agents during businessrelated transactions and emphasize the need to

Table 8 Variance decomposition estimates

\begin{tabular}{|c|c|c|c|c|c|c|c|}
\hline \multicolumn{8}{|c|}{ Variance decomposition of $\boldsymbol{\Delta} \ln (\mathrm{NEW})$} \\
\hline Months & SE. & $\Delta \ln (\mathrm{NEW})$ & $\boldsymbol{\Delta} \ln (\mathrm{CDAM})$ & $\Delta \ln (\mathrm{CPI})$ & $\boldsymbol{\Delta} \ln (\mathrm{ESR})$ & $\boldsymbol{\Delta} \ln (\mathrm{GDPPC})$ & $\boldsymbol{\Delta} \ln (\mathrm{MS})$ \\
\hline January 2021 & 2.654876 & 99.44022 & 0.434700 & 0.025601 & 0.002212 & 0.083785 & 0.013486 \\
\hline February 2021 & 2.659966 & 99.07438 & 0.689012 & 0.043968 & 0.033965 & 0.099237 & 0.059434 \\
\hline March 2021 & 2.660194 & 99.06047 & 0.696863 & 0.046784 & 0.036024 & 0.099241 & 0.060616 \\
\hline April 2021 & 2.660198 & 99.06023 & 0.696866 & 0.046926 & 0.036051 & 0.099290 & 0.060632 \\
\hline May 2021 & 2.660198 & 99.06022 & 0.696872 & 0.046927 & 0.036052 & 0.099294 & 0.060639 \\
\hline June 2021 & 2.660198 & 99.06021 & 0.696873 & 0.046927 & 0.036052 & 0.099294 & 0.060639 \\
\hline July 2021 & 2.660198 & 99.06021 & 0.696873 & 0.046927 & 0.036052 & 0.099294 & 0.060639 \\
\hline August 2021 & 2.660198 & 99.06021 & 0.696873 & 0.046927 & 0.036052 & 0.099294 & 0.060639 \\
\hline September 2021 & 2.660198 & 99.06021 & 0.696873 & 0.046927 & 0.036052 & 0.099294 & 0.060639 \\
\hline \multicolumn{8}{|c|}{ Variance decomposition of $\boldsymbol{\Delta} \ln (\mathrm{NEWF})$} \\
\hline Months & SE. & $\boldsymbol{\Delta} \ln (\mathrm{NEWF})$ & $\boldsymbol{\Delta} \ln (\mathrm{CDAM})$ & $\Delta \ln (\mathrm{CPI})$ & $\Delta \ln (\mathrm{ESR})$ & $\Delta \ln (\mathrm{GDPPC})$ & $\mathbf{\Delta} \ln (\mathrm{MS})$ \\
\hline February 2021 & 2.259445 & 99.56116 & 0.145534 & 0.167805 & 0.101744 & 0.023752 & $2.25 \mathrm{E}-08$ \\
\hline March 2021 & 2.259966 & 99.54227 & 0.158234 & 0.172984 & 0.101747 & 0.024764 & $2.26 \mathrm{E}-08$ \\
\hline April 2021 & 2.259984 & 99.54074 & 0.158641 & 0.174017 & 0.101820 & 0.024786 & $2.26 \mathrm{E}-08$ \\
\hline May 2021 & 2.259985 & 99.54066 & 0.158651 & 0.174058 & 0.101841 & 0.024786 & $2.26 \mathrm{E}-08$ \\
\hline June 2021 & 2.259985 & 99.54066 & 0.158654 & 0.174059 & 0.101842 & 0.024786 & $2.26 \mathrm{E}-08$ \\
\hline July 2021 & 2.259985 & 99.54066 & 0.158654 & 0.174059 & 0.101842 & 0.024786 & $2.26 \mathrm{E}-08$ \\
\hline August 2021 & 2.259985 & 99.54066 & 0.158654 & 0.174059 & 0.101842 & 0.024786 & $2.26 \mathrm{E}-08$ \\
\hline September 2021 & 2.259985 & 99.54066 & 0.158654 & 0.174059 & 0.101842 & 0.024786 & $2.26 \mathrm{E}-08$ \\
\hline
\end{tabular}

Note: $\boldsymbol{\Delta}$ shows the first difference, ln shows natural logarithm, CDAM shows carbon damages, SQDAM shows a square of CDAM, CPI shows inflation, ESR shows environmental sustainability rating, GDPPC shows per capita GDP and MS shows money supply 
implement entire COVID-19 guidelines in the buying and selling process. Thus, the need to maintain social distancing is pivotal to minimize newly infected cases.

ii) To regulate environmental policies that would reduce high carbon costs to achieve the healthcare sustainability agenda. The rise in carbon emissions led to an increase in patient's illness and low immune system, which quickly infected from coronavirus disease. The need to improve environmental sustainability ratings is imperative to escape from coronavirus disease by achieving a healthy immune system, using nutritional diets and supplements, and civilizing sanitation facilities.

iii) The soundness of economic and healthcare policies deemed desirable to improve healthcare logistics infrastructure. A rise in $R \& D$ spending in launching the coronavirus vaccine, preventing coronavirus policies, involved community stakeholders and local investors, avoid massive gatherings and increase self-awareness and protocol, largely supporting the healthcare sustainability agenda.

iv) Financial development is essential to begin economic activities while maintaining commodity price level reduces economic sufferings from the vulnerable segment of the society. Hence, it is essential to improve stock market efficiency through strict compliance of COVID-19 cases, while government should have to subsidize food products by lowering their prices to support the lower-income group in the wake of the COVID-19 pandemic, and

v) Human development formation is vital to understand all the three possible indices of human progress related to a healthy life, knowledge diffusion and decent living standards. A healthy and informative person may be able to compliance all suggested measures to contain coronavirus cases. Hence, it is essential to move forward to achieve healthcare sustainability across countries.

Thus, the need to re-focus on earlier preventive policies and re-address new possible wave of coronavirus cases to contain infectious diseases required at nipping in the bud.

Acknowledgements Researchers Supporting Project number (RSP2021/87), King Saud University, Riyadh, Saudi Arabia.

Author contribution MKA: Conceptualization, Methodology, WritingReviewing and Editing. BU: Software, Formal Analysis. SH: Methodology Formal Analysis AAN: Supervision, Resources, Software. SEA: Formal Analysis, Resources. KZ. Software, Formal Analysis, Resources. MMQA: Resources, visualization, Formal Analysis.
Funding Researchers Supporting Project number (RSP-2021/87), King Saud University, Riyadh, Saudi Arabia

Data Availability The data is freely available at Worldometer (2020) at https://www.worldometers.info/coronavirus/ and World Development Indicators published by World Bank (2020) at https://databank. worldbank.org/source/world-development-indicators.

\section{Declarations}

Ethical approval Not applicable.

Consent to participate All authors are equally participated in the study.

Consent for publication All authors allow the publication of the paper.

Competing interests The authors declare that they have no conflict of interest.

\section{References}

Abdi M (2020) Coronavirus disease 2019 (COVID-19) outbreak in Iran: actions and problems. Infect Control Hosp Epidemiol 41(6):754 755

Adalja AA, Toner E, Inglesby TV (2020) Priorities for the US health community responding to COVID-19. Jama 323(14):1343-1344

Ahmad S, Islam T, Sadiq M, Kaleem A (2021) Promoting green behavior through ethical leadership: a model of green human resource management and environmental knowledge. Leadersh Org Dev J aheadof-print. https://doi.org/10.1108/LODJ-01-2020-0024

Ahmed I, Islam T, Ahmad S, Kaleem A (2021) A COVID-19 contextual study of customers' mistreatment and counterproductive work behavior at coffee cafés. Br Food $J$ ahead-of-print. https://doi.org/10. 1108/BFJ-07-2020-0664

Akseer N, Kandru G, Keats EC, Bhutta ZA (2020) COVID-19 pandemic and mitigation strategies: implications for maternal and child health and nutrition. Am J Clin Nutr 112(2):251-256

Albuquerque MS, Lyra TM, Melo AP, Valongueiro SA, Araújo TV, Pimentel C, ..., Penn-Kekana L (2019) Access to healthcare for children with Congenital Zika Syndrome in Brazil: perspectives of mothers and health professionals. Health Pol Plann 34(7):499-507

Allam Z, Jones DS (2020) On the coronavirus (COVID-19) outbreak and the smart city network: universal data sharing standards coupled with artificial intelligence (AI) to benefit urban health monitoring and management. In Healthcare (Vol. 8, No. 1, p. 46). Multidisciplinary Digital Publishing Institute

Anser MK, Yousaf Z, Khan MA, Nassani AA, Alotaibi SM, Abro MMQ, ..., Zaman K (2020a) Does communicable diseases (including COVID-19) may increase global poverty risk? A cloud on the horizon. Environ Res 187:109668

Anser MK, Islam T, Khan MA, Zaman K, Nassani AA, Askar SE, ... Kabbani A (2020b) Identifying the potential causes, consequences, and prevention of communicable diseases (including COVID-19). BioMed Res Int, Article ID 8894006, https://doi.org/10.1155/2020/ 8894006

Anser MK, Yousaf Z, Khan MA, Voo XH, Nassani AA, Alotaibi SM, Abro MMQ, Zaman K (2020c) The impacts of COVID-19 measures on global environment and fertility rate: double coincidence. Air Qual Atmos Health 13(9):1083-1092

Anser MK, Khan MA, Zaman K, Nassani AA, Askar SE, Abro MMQ, Kabbani A (2021) Financial development during COVID-19 
pandemic: the role of coronavirus testing and functional labs. Finan Innov 7(1):1-13

Bai Y, Yao L, Wei T, Tian F, Jin DY, Chen L, Wang M (2020) Presumed asymptomatic carrier transmission of COVID-19. Jama 323(14): 1406-1407

Balsalobre-Lorente D, Driha OM, Bekun FV, Sinha A, Adedoyin FF (2020) Consequences of COVID-19 on the social isolation of the Chinese economy: accounting for the role of reduction in carbon emissions. Air Qual Atmos Health 13(12):1439-1451

Banthin J, Simpson M, Buettgens M, Blumberg LJ, Wang R (2020) Changes in health insurance coverage due to the COVID-19 recession: preliminary estimates using microsimulation. Urban Institute, Washington, DC

Bartik AW, Bertrand M, Cullen Z, Glaeser EL, Luca M, Stanton C (2020) The impact of COVID-19 on small business outcomes and expectations. Proc Natl Acad Sci 117(30):17656-17666

Batool R, Sharif A, Islam T, Zaman K, Shoukry AM, Sharkawy MA, Gani S, Aamir A, Hishan SS (2019) Green is clean: the role of ICT in resource management. Environ Sci Pollut Res 26(24):2534125358

Bloom DE, Cadarette D (2019) Infectious disease threats in the twentyfirst century: strengthening the global response. Front Immunol 10: 549. https://doi.org/10.3389/fimmu.2019.00549

BourBour F, Mirzaei Dahka S, Gholamalizadeh M, Akbari ME, Shadnoush M, Haghighi M, Taghvaye-Masoumi H, Ashoori N, Doaei S (2020) Nutrients in prevention, treatment, and management of viral infections; special focus on coronavirus. Arch Physiol Biochem:1-10. https://doi.org/10.1080/13813455.2020.1791188

Brownstone ND, Thibodeaux QG, Reddy VD, Myers BA, Chan SY, Bhutani T, Liao W (2020) Novel coronavirus disease (COVID-19) and biologic therapy in psoriasis: infection risk and patient counseling in uncertain times. Dermatol Ther 10(3):339-349

Cavanagh G, Wambier CG (2020) Rational hand hygiene during the coronavirus 2019 (COVID-19) pandemic. J Am Acad Dermatol 82(6):e211

Centers for Disease Control and Prevention (2017) 2014-2016: Ebola outbreak in West Africa. Available online at: https://www.cdc.gov/ vhf/ebola/history/2014-2016-outbreak/index.html (accessed 12th February, 2019)

Chesak J (2020) Can we learn anything from SARS to fight COVID-19? Available at: https://www.healthline.com/health-news/hasanything-changed-since-the-2003-sars-outbreak (Accessed on 17th March, 2020)

Eissa N (2020) Pandemic preparedness and public health expenditure. Economies 8(3):60. https://doi.org/10.3390/economies8030060

Fukuda H, Yano Y, Sato D, Ohde S, Noto S, Watanabe R, Takahashi O (2020) Healthcare expenditures for the treatment of patients infected with hepatitis C virus in Japan. PharmacoEconomics 38:297-306

Gaffney C, Eeckels B (2020) COVID-19 and tourism risk in the Americas. J Lat Am Geogr 19(3):308-313

Govindan K, Mina H, Alavi B (2020) A decision support system for demand management in healthcare supply chains considering the epidemic outbreaks: a case study of coronavirus disease 2019 (COVID-19). Transport Res E: Logistics Transport Rev 138: 101967

Grasselli G, Pesenti A, Cecconi M (2020) Critical care utilization for the COVID-19 outbreak in Lombardy, Italy: early experience and forecast during an emergency response. Jama 323(16):1545-1546

Hadjidemetriou GM, Sasidharan M, Kouyialis G, Parlikad AK (2020) The impact of government measures and human mobility trend on COVID-19 related deaths in the UK. Transport Res Interdiscip Perspect 6:100167

Han P, Cai Q, Oda T, Zeng N, Shan Y, Lin X, Liu D (2021) Assessing the recent impact of COVID-19 on carbon emissions from China using domestic economic data. Sci Total Environ 750:141688
Humpe A, McMillan D (2020) The Covid-19 stock market puzzle and money supply in the US. Econ Bull 40(4):3104-3110

Institute for Health Metrics and Evaluation (2019) GBD results tool. Available online at: http://ghdx.healthdata.org/gbd-results-tool. (Accessed 12th February, 2019)

Islam T, Ali G, Asad H (2019) Environmental CSR and proenvironmental behaviors to reduce environmental dilapidation. Manag Res Rev 42(3):332-351

Islam T, Khan MM, Ahmed I, Mahmood K (2020a) Promoting in-role and extra-role green behavior through ethical leadership: mediating role of green HRM and moderating role of individual green values. Int J Manpow. https://doi.org/10.1108/IJM-01-2020-0036 ahead-ofprint

Islam T, Mahmood K, Sadiq M, Usman B, Yousaf SU (2020b) Understanding knowledgeable workers' behavior toward COVID19 information sharing through WhatsApp in Pakistan. Front Psychol 11. https://doi.org/10.3389/fpsyg.2020.572526

Kang L, Li Y, Hu S, Chen M, Yang C, Yang BX et al (2020a) The mental health of medical workers in Wuhan, China dealing with the 2019 novel coronavirus. Lancet Psychiatry 7(3):e14

Kang L, Ma S, Chen M, Yang J, Wang Y, Li R et al (2020b) Impact on mental health and perceptions of psychological care among medical and nursing staff in Wuhan during the 2019 novel coronavirus disease outbreak: a cross-sectional study. Brain Behav Immun 87:1117

Kansiime MK, Tambo JA, Mugambi I, Bundi M, Kara A, Owuor C (2021) COVID-19 implications on household income and food security in Kenya and Uganda: findings from a rapid assessment. World Dev 137:105199

Kum FV, Olayiwola S, Aloysius NM (2019) The impact of Ebola virus disease on government expenditure in Sierra Leone. In Sociocultural dimensions of emerging infectious diseases in Africa (pp. 75-90). Springer, Cham

Kutscher E, Greene RE (2020) A harm-reduction approach to coronavirus disease 2019 (COVID-19) - safer socializing. In JAMA Health Forum (Vol. 1, No. 6, pp. e200656-e200656). American Medical Association

Le Quéré C, Jackson RB, Jones MW, Smith AJ, Abernethy S, Andrew $\mathrm{RM}, \ldots$, Peters GP (2020) Temporary reduction in daily global CO 2 emissions during the COVID-19 forced confinement. Nat Clim Chang 10(7):647-653

Lima CKT, de Medeiros Carvalho PM, Lima IDAAS, de Oliveira Nunes JVA, Saraiva JS, de Souza RI, ..., Neto MLR (2020) The emotional impact of coronavirus 2019-nCoV (new coronavirus disease). Psychiatry Res 287:112915

Lima-Costa MF, Mambrini JVDM, Andrade FBD, Peixoto SWV, Macinko J (2020) Social distancing, use of face masks and hand washing among participants in the Brazilian Longitudinal Study of Aging: the ELSI-COVID-19 initiative. Cadernos de Saúde Pública 36: 00193920

Murthy S, Gomersall CD, Fowler RA (2020) Care for critically ill patients with COVID-19. Jama 323(15):1499-1500

Njau J, Janta D, Stanescu A, Pallas SS, Pistol A, Khetsuriani N, Reef S, Ciurea D, Butu C, Wallace AS, Zimmerman L (2019) Assessment of economic burden of concurrent measles and rubella outbreaks, Romania, 2011-2012. Emerg Infect Dis 25(6):1101-1109

Ogen Y (2020) Assessing nitrogen dioxide (NO2) levels as a contributing factor to the coronavirus (COVID-19) fatality rate. Sci Total Environ 726:138605

Partlow J (2016) As Zika virus spreads, El Salvador asks women not to get pregnant until 2018. Washington Post, 117-20. Available from: https://www.washingtonpost.com/world/the americas/as-zikavirus-spreads-el-salvador-asks-women-not-to-get-pregnant-until2018/2016/01/22/1dc2dadcc11f-11e5-98c8-7fab78677d51 story. html. (Accessed on 10th October, 2020) 
Pedrazzoli D, Borghi J, Viney K, Houben RMGJ, Lönnroth K (2019) Measuring the economic burden for TB patients in the End TB Strategy and Universal Health Coverage frameworks. Int J Tuberculosis Lung Dis 23(1):5-11

Pulia MS, O’Brien TP, Hou PC, Schuman A, Sambursky R (2020) Multitiered screening and diagnosis strategy for COVID-19: a model for sustainable testing capacity in response to pandemic. Ann Med 52(5):207-214

Razai MS, Doerholt K, Ladhani S, Oakeshott P (2020) Coronavirus disease 2019 (covid-19): a guide for UK GPs. BMJ 368. https://doi.org/ 10.1136/bmj.m800

Rupani PF, Nilashi M, Abumalloh RA, Asadi S, Samad S, Wang S (2020) Coronavirus pandemic (COVID-19) and its natural environmental impacts. Int J Environ Sci Technol 17:4655-4666

Saha J, Chouhan P (2020) Indoor air pollution (IAP) and pre-existing morbidities among under-5 children in India: are risk factors of coronavirus disease (COVID-19)? Environ Pollut 266:115250

Saunders-Hastings PR, Krewski D (2016) Reviewing the history of pandemic influenza: understanding patterns of emergence and transmission. Pathogens 5(4):1-19

Schwarz C (2021) Freed from insurance: health care sharing ministries and the moralization of health care. Soc Sci Med 268:113453

Shereen MA, Khan S, Kazmi A, Bashir N, Siddique R (2020) COVID-19 infection: origin, transmission, and characteristics of human coronaviruses. J Adv Res 24:91-98

Silaswara D, Gunawan I, Fung TS (2020) Analysis of money circulating in Indonesia during Covid-19 pandemic. Primanomics: Jurnal Ekonomi \& Bisnis 18(3):36-46

Silva RRD, Santos MBD, Santos ADD, Tavares DDS, Santos PLD (2020) Coronavirus disease and basic sanitation: too early to be worried? Rev Soc Bras Med Trop 53:1-5

Silveira MR, Junior NFF, Cocco RG, Felácio RM, Rodrigues LA (2020) Novel coronavirus (Sars-Cov-2): spatial diffusion and another level for the socialization of investments in Brazil. Revista Brasileira de Estudos Urbanos e Regionais 22:e202024en

Sinclair RR, Allen T, Barber L, Bergman M, Britt T, Butler A, Ford M, Hammer L, Kath L, Probst T, Yuan Z (2020) Occupational health science in the time of COVID-19: now more than ever. Occup Health Sci 4:1-22

SinoBiological (2020) SARS-CoV-2 (COVID-19 virus) research. Beijing, P.R. China. Online available at: https://www. sinobiological.com/ (accessed on 11Novemver, 2020)

Smith AC, Thomas E, Snoswell CL, Haydon H, Mehrotra A, Clemensen J, Caffery LJ (2020) Telehealth for global emergencies: implications for coronavirus disease 2019 (COVID-19). J Telemed Telecare 26(5):309-313

The New York Times (2020) Coronavirus may add billions to the nation's health care bill. Online available at: https://www.nytimes. com/2020/03/28/health/coronavirus-insurance-premium-increases. $\mathrm{html}$ (accessed on 30th May, 2020)

Ung COL (2020) Community pharmacist in public health emergencies: quick to action against the coronavirus 2019-nCoV outbreak. Res Soc Adm Pharm 16(4):583-586

Wang Y, Tian H, Zhang L, Zhang M, Guo D, Wu W, ..., Liu B (2020) Reduction of secondary transmission of SARS-CoV-2 in households by face mask use, disinfection and social distancing: a cohort study in Beijing, China. BMJ Global Health 5(5):e002794

Ward T, Sugrue D, Hayward O, McEwan P, Anderson SJ, Lopes S, Punekar Y, Oglesby A (2020) Estimating HIV management and comorbidity costs among aging HIV patients in the United States: a systematic review. J Manag Care Special Pharm 26(2):104-116

Wilder-Smith A, Freedman DO (2020) Isolation, quarantine, social distancing and community containment: pivotal role for old-style public health measures in the novel coronavirus (2019-nCoV) outbreak. J Travel Med 27(2):taaa020

Wimalawansa SJ (2020) Global epidemic of coronavirus-Covid-19: what can we do to minimize risks. Eur J Biomed 7(3):432-438

World Bank (2020) World development indicators. World Bank, Washington DC

World Health Organization (2018). Global Health Observatory (GHO) data. Available at: https://www.who.int/gho/hiv/en/ (Accessed on 28th March 2020)

World Health Organization (2019). Cholera. Available online at: https:// www.who.int/news-room/fact-sheets/detail/cholera (accessed 28 March 2020)

Worldometer (2020) COVID-19 pandemic: coronavirus cases. Online available at: https://www.worldometers.info/coronavirus/ (accessed on 19th October, 2020)

Wu HL, Huang J, Zhang CJ, He Z, Ming WK (2020) Facemask shortage and the novel coronavirus disease (COVID-19) outbreak: reflections on public health measures. EClinicalMedicine 21:100329

Xiang YT, Yang Y, Li W, Zhang L, Zhang Q, Cheung T, Ng CH (2020) Timely mental health care for the 2019 novel coronavirus outbreak is urgently needed. Lancet Psychiatry 7(3):228-229

Publisher's note Springer Nature remains neutral with regard to jurisdictional claims in published maps and institutional affiliations. 